\title{
Retail therapy
}

The publication on 16 July of Better leadership for tomorrow, the NHS leadership review, ${ }^{1}$ the independent review commissioned by the Department of Health, did not cause much of a stir overshadowed as it was by the Secretary of State's somewhat combative statement on hospital doctors and seven-day working made the previous day. ${ }^{2}$

The review's author, Lord Rose, former Marks and Spencer executive, summarised his aim as being to make people better qualified to manage and to lead in the NHS, and produced 19 recommendations (a refreshingly small number for a health service review). The recommendations start with two preconditions - a service-wide communication strategy for cascading news and good practice, and a succinct NHS handbook summarising NHS core values. A single communication strategy to reach all staff, trusts and commissioning groups certainly sounds worthwhile, though it would present problems in avoiding overload and an editorial headache for the webmaster. Creating a handbook should be more straightforward - though it is difficult to see the core values would differ greatly from those in the NHS constitution which 'establishes the principles and values of the NHS in England', published in its most recent form barely two weeks after the Rose report; ${ }^{3}$ but admittedly the style could be racier.

Rose's specific recommendations then address training, performance management, bureaucracy and management support. Training, he argues, should be coordinated centrallya responsibility to be vested in Health Education England; he argues this would provide a consistent management training regime across clinical, administrative and nursing/ ancillary staff; although the report also advocates pluralism and innovation in training courses. Accredited courses would lead to a qualification for middle managers, equipping them to enter a talent pool for senior management anywhere in the NHS. It is likely that hospital doctors - with memories of multidisciplinary mandatory trainings in their trusts - will view much of this askance.

Performance management in the current NHS is judged as weak; although again hospital clinicians reading Rose's strictures on the shortcomings of appraisal systems, lack of objective setting and absence of $360^{\circ}$ appraisal may feel that physicians are rather ahead of the game. However, in particular they may wonder at the contention that talent cannot be managed without a single competency framework for all NHS staff. While Rose echoes the oft-repeated criticism that the NHS works in silos, it is worth recalling that silos, however undesirable, developed because in a field as complex as delivering modern medicine, specialisation of the work force whether in finance, procurement or the clinic - is essential for high quality service.

The one area that doctors will indeed welcome in the report is his initiative to cut bureaucracy. The Care Quality Commission, Monitor, the NHS Trust Development Authority (responsible for oversight of non-foundation trusts) are described as regulators in overdrive, spawning an industry of often overlapping data collection. Yet while the issue is well aired, and the recommendation to amalgamate Monitor and the Trust Development Authority has some force, many of the recommendations for cutting the burden are relatively anodyne - good housekeeping reviews, less committee work, non-executive directors to communicate concerns around request feasibility to the requesting organisation, and a gatekeeper function remitted to clinical commissioning groups. Not a bonfire!

So what will change as a result of this report? It has been suggested that lack of urgency in publishing this report (delivered to the Department of Health six months before publication) was attributable to the wish of the government to leave it on the 'back burner of the back burner'. In addition, it has been reported in much of the press as simply a wideranging attack on the quality of NHS management. ${ }^{5}$ If the Daily Telegraph is to be believed, ${ }^{6}$ the report provided Simon Stevens, chief executive of NHS England, with his most quotable quote to date: 'The complexity of leading improvement of the National Health Service more than rivals that of selling underwear'. So maybe the auguries are not good for its wholesale adoption. But - returning again to the imputed thoughts of the hospital doctor - they will surely endorse Rose's view that there is insufficient management and leadership capability to deal effectively with the challenges of change in the NHS.

In some ways this report provides an interesting parallel, as well as a coda, to previous reports, when the government also turned to the retail trade, to Sir Roy Griffiths while a director of J Sainsbury plc, to enquire into NHS management. ${ }^{7}$ One of Griffith's key recommendations was that general managers

$\begin{array}{ll}\text { Members of the editorial board } \\ \text { Professor Humphrey Hodgson } & \text { Dr Cordelia Coltart } \\ \text { Editor } & \text { International editor } \\ \text { Dr Paul Grant } & \text { Cono Ariti } \\ \text { Editorial registrar } & \text { Statistical editor }\end{array}$

Dr Na'eem Ahmed Paul Belcher Dr Rodger Charlton Dr Tahseen Chowdhury Nick Cork Dr Kate Evans Professor Brian Hurwitz
Dr Angela King Professor Martin McKee Dr Mehool Patel Dr Roby Rakhit Dr Ian Starke Dr Kevin Stewart Professor Cameron Swift 
should be introduced throughout the NHS, and their primary role should be to provide leadership to capitalise on 'existing high levels of dedication and expertise among NHS staff of all disciplines, and to stimulate initiative, urgency and vitality'. That management structure in the NHS broadly survives to this day, and many of the issues raised in that report closer involvement of clinicians in management, appropriate management training inside and outside the NHS, and promotion of professional perceptions of what the NHS can and should provide - still resonate and are echoed by Rose. Griffiths' admonishment to the secretary of state of the day in Mrs Thatcher's government that 'staff in the NHS have to be assured that when changes are being made, demands on them will as far as possible be part of an orderly process' provides an interesting counterpoise to Rose's comment that within the NHS there is 'widespread change fatigue and an irritation that new changes are not given sufficient time to bed in'. Plus ça change.

\section{References}

1 Lord Rose. Better leadership for tomorrow - NHS leadership review. London: DoH, 2015. Available online at www.gov.uk/government/ publications/better-leadership-for-tomorrow-nhs-leadership-review [Accessed 29 July 2015].
2 Hunt declares seven-day NHS ultimatum in 'war with doctors'. The Week, 16 July 2015. Available online at www.theweek.co.uk/63698/ hunt-declares-seven-day-nhs-ultimatum-in-war-with-doctors [Accessed 29 July 2015].

3 Department of Health. The NHS constitution for England: the NHS belongs to us all. London: DoH, 2012 (updated 2015). Available online at www.gov.uk/government/uploads/system/uploads/attachment_data/ file/448466/NHS_Constitution_WEB.pdf [Accessed 29 July 2015].

4 Neville S, Rigby E. Rose report criticising management of NHS 'put on back burner'. Financial Times, 16 February 2015. Available online at www.ft.com/cms/s/0/25369fd2-b14f-11e4-a830-00144feab7de. html [Accessed 29 July 2015].

5 Cooper C. NHS has a 'chronic shortage of good leaders', report claims. The Independent, 16 July 2015. Available online at www. independent.co.uk/life-style/health-and-families/health-news/nhshas-a-chronic-shortage-of-good-leaders-report-claims-10394623. html [Accessed 29 July 2015].

6 Swinford S. Running the NHS is harder than selling underwear: head of health service hits out at M\&S boss. The Telegraph, 2015. Available online at www.telegraph.co.uk/news/nhs/11753540/Running-theNHS-is-harder-than-selling-underwear-head-of-health-service-hitsout-at-MandS-boss.html [Accessed 29 July 2015].

7 Griffith ER. Griffiths management enquiry. Available online at www.nhshistory.net/griffiths.html [Accessed 29 July 2015].

Humphrey Hodgson

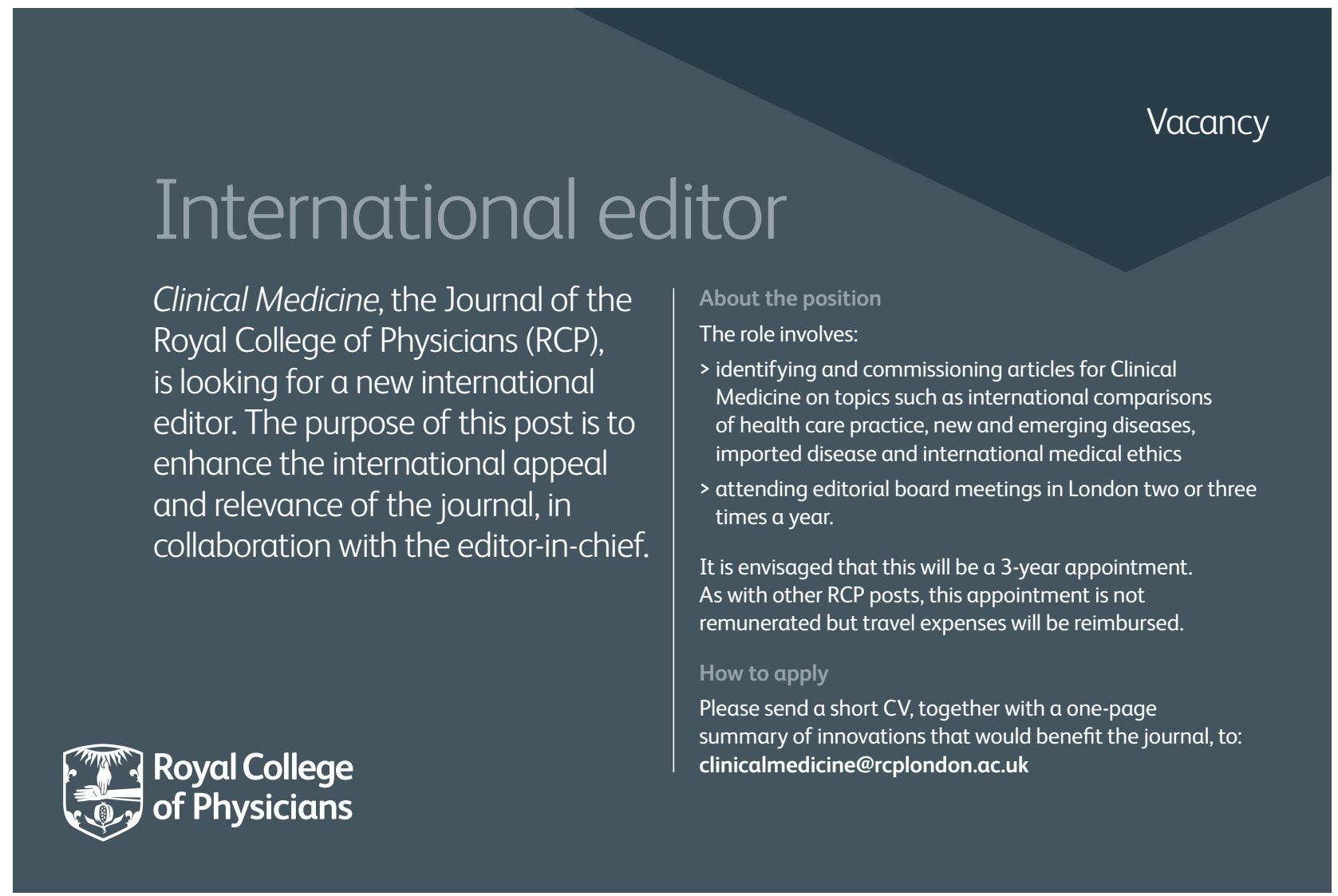

